\title{
ESTAKHR PROJECT - THIRD PRELIMINARY REPORT OF THE JOINT MISSION OF THE IRANIAN CENTER FOR ARCHAEOLOGICAL RESEARCH, THE PARSA-PASARGADAE RESEARCH FOUNDATION AND THE SAPIENZA UNIVERSITY OF ROME, ITALY
}

Maria Vittoria Fontana - Sapienza University of Rome, Dept. of Antiquities Ahmad Ali Asadi - Parsa-Pasargadae Research Foundation -

Martina Rugiadi - The Metropolitan Museum of Art of New York Anna Candida Felici - Sapienza University of Rome, Dept. of Basic and Applied Sciences for Engineering Agnese Fusaro - Serenella Mancini - Sapienza University of Rome, Dept. of Antiquities

This report presents the preliminary results of the study of the pottery collected during the excavation campaign carried out in 2012 in the framework of the joint Iranian-Italian Archaeological Mission in Estakhr. The ceramic finds relate to a time span ranging from the $9^{\text {th }}$ to the $12^{\text {th }}$ century, corresponding to the occupation phases identified within the stratigraphy. Moreover, the use of archaeometry made it possible to identify both imported and locally manufactured wares.

Keywords: Estakhr; Iran; Early Islamic; archaeology; pottery

The third season of archaeological activities of the joint Iranian-Italian Archaeological Mission in Estakhr was carried out from 8 May to 2 June 2015 under the joint direction of Maria Vittoria Fontana and Ahmad Ali Asadi. ${ }^{1}$ The research team was composed of Martina Rugiadi, field director, archaeologist and ceramologist, Anna Candida Felici, archaeometrist, Agnese Fusaro, ceramologist, and Serenella Mancini, ceramologist.

The aim of this season was to classify and research the ceramic finds excavated in the second campaign of the Estakhr Project (autumn 2012) and to assess the chronology of the phases identified in the trench. ${ }^{2}$ This plan was approved by the Iranian counterpart after their decision to interrupt the project.

The excavated trench was situated in the area west and northwest of the mosque remains (fig. 1), starting from the qibli wall opening detected during the first season. ${ }^{3}$ The trench, oriented east-west and orthogonal to the qibli wall, measured $20.90 \times 2 \mathrm{~m}$, except in the area close to the mosque where its width measured $4.49-4.90 \mathrm{~m} .{ }^{4}$ At least eight phases were identified. Among them, a paved street and its sewer are particularly relevant. Their orientation and development seem to define a main quarter that was situated to the west of the mosque.

1 The third campaign was funded by the Sapienza University of Rome, the Max van Berchem Foundation of Geneva and the Italian Ministry of Foreign Affairs.

2 Chegini et al. 2013.

3 Fontana et al. 2012; Chegini et al. 2013, fig. 2.

4 The entire excavated area was filled and is now (2015) no longer recognizable. 
Due to the short length of this campaign we decided not to take into consideration the pottery from the very upper layers SU 101, 112 and 116, corresponding to Phase $8 .{ }^{5}$ For the same reason only the diagnostic sherds have been classified and analysed; nonetheless the non-diagnostic material has been divided into large groups (coarse ware made of fabric group 1, coarse ware made of fabric group 4, fine ware) and the related specimens have been counted with a view to future statistical analysis.

The pottery corpus classified to date totals 6206 artefacts, both glazed and unglazed, also including four sphero-conical vessels, three small animal terracotta figurines, pipes, baked bricks and objects relating to the ceramic production process.

A very important part of the field work concerned the archaeometric analyses (see Felici, below), and its valuable input will help to formulate a mineralogical-petrographic and chemical characterization, as precise as possible, of the different ceramic productions constituting the Estakhr corpus. ${ }^{6}$

In order to link this preliminary report to previous publications on the Estakhr Project, and in particular to gain a better understanding of the ceramic material within the related archaeological contexts, herein we have decided to present the pottery assemblages of the stratigraphic units mentioned in the 2013 report. $^{7}$

Maria Vittoria Fontana - Ahmad Ali Asadi - Martina Rugiadi

\section{POTTERY FINDS: A GENERAL OVERVIEW ${ }^{8}$}

Before analysing the ceramic assemblages, presented on the basis of stratigraphic units and archaeological phases, it is worth considering the pottery corpus as a whole. As a matter of fact, from a first examination, it seems clear that the excavated ceramic material is very homogeneous as the stratigraphy relates to a relatively short chronological time span. The following brief notes outline an overall framework of the productions so far identified within the unglazed and the glazed ceramic classes by describing and defining some technological and decorative features for each ware or group of wares.

First of all some considerations can be proposed on the existence of local ceramic manufacturing. The identification of a substantial amount of fragments of moulds (fig. 2), used for shaping and decorating vessel bodies, testifies that most of the unglazed fine jugs with moulded relief decoration found in the excavation were manufactured in the area. Moreover the finding of items belonging to kiln furniture - two kiln pegs, one bearing different glazes drops (sample 13, fig. 3; see Felici, below) - suggests that some glazed wares were manufactured locally, at least in the last important occupation phases of Estakhr

5 Chegini et al. 2013, 12.

6 Archaeometric analyses were performed in Iran during the campaign. Petrographic and geochemical analyses are currently being carried out by Dr Fabio Bellatreccia of the Department of Geological Science - Roma Tre University, Rome.

7 Chegini et al. 2013

8 In 1939 E. Schmidt published some samples of pottery collected during the excavations carried out by E. Herzelfd until 1934 (Schmidt 1939, 111-118), in order to give “[...] a rough idea of the ceramic wealth of Muslim Istakhr” (Schmidt 1939, 118). Unfortunately this report was too short and no other comprehensive contributions on pottery were published since then, except a few ones focused on specific ceramic categories (see Nováček 2009). 
( $11^{\text {th }}$ century), as the kiln pegs were collected respectively in SU 120 (Phase 5) and SU 142 (Phase 7).

In addition, the macroscopic observation ${ }^{9}$ of fabrics of both unglazed and glazed vessels and the strong similarity of the most common fabrics (see below) with the ceramic body of the above-mentioned evidence of local production leads us to suggest that most of the unglazed wares and at least some of the coarsest glazed vessels were locally produced. ${ }^{10}$

These preliminary hypotheses could be revised or confirmed by further archaeometric analyses, the ultimate aim of which would be to produce a comprehensive provenance study (see Felici, below).

\subsection{Unglazed pottery}

Most of the unglazed wares have coarse or medium-coarse fabrics belonging to fabricgroups 1 and 4 (fig. 4). Although they present different features that allow them to be distinguished, these fabrics are probably closely related to each other. Indeed they seem to have been produced by mixing the same clay and mineral inclusions; the difference between them may be due to the firing temperature and atmosphere, as suggested by the colours of both the matrix and temper: ${ }^{11}$ the buff colour and black temper of fabric group 1 may suggest a higher firing temperature than fabric group 4, which is characterized by a reddish/pinkish matrix and dark red-brown mineral inclusions.

Moreover, vessels made of fabrics 4 are frequently characterized by lighter-whitish surfaces derived from a peculiar process due to the interaction of many factors, mostly the composition of the clay and the firing temperature ${ }^{12}$ (fig. 5). This process seems common in Estakhr local production as many unglazed wares have distinct whitish surfaces associated with a reddish clay body (see also fine unglazed jugs).

As for the forms, there is a predominance of closed vessels, especially small and medium jars or jugs with vertical handles; there are a few big jars with rim diameters of around $25 \mathrm{~cm}$ and usually quite a high neck; closed forms also include a very small number of pots, sometimes with small handles. Open forms consist of basins, the most frequent type being small basins, not exceeding $15 \mathrm{~cm}$ in diameter, with almost vertical straight or slightly curved walls, a flat base and triangular, rectangular or rounded rims thickened outwards. Among the coarse wares, some large coarse lids or trays were also recognized.

A good number of vessels, generally closed forms, show combed incised and carved decorations, sometimes with finger impressions added on the rim; large jars may also be characterized by applied strips. Some vessels are covered by slip or have painted decoration; those with black coating and black painting are more common than the red ones. Specimens decorated with red or black painting, also associated with incised and carved decoration and/or mouldings (fig. 6), are also frequent. ${ }^{13}$ Within the group of

$9 \quad$ Lenses with 20X magnification were used.

10 This hypothesis, first suggested by Schmidt $(1970,69)$, is also corroborated by the finding of pottery slags and moulds during a short survey in the Estakhr area in 2012 (Chegini et al. 2013, n. 6).

11 See, for example, Mirti 1998; Mirti et al. 2004; Maggetti et al. 2011.

12 Cuomo di Caprio 2007, 311.

13 Chegini et al. 2013, 10. 
vessels completely covered by black slip, one form in particular stands out: small and medium handled jars or jugs with a carinated body and quite a high cylindrical neck.

A very small number of fragments have been ascribed with certainly to cooking pots, mostly with globular or sub-globular bodies and a triangular rim thickened inwards (Inv. no. ES 135, fig. 7); they are made of fabric 5 (fig. 8), probably an iron-rich clay, mainly mixed with quartz temper and black mineral inclusions.

The corpus also comprises several fine specimens, mainly represented by handled jugs with globular or sub-globular bodies and disc bases. There are fewer fragments belonging to small lids, probably associated with the jugs, as well as bowls with thin walls and small pots. These wares are made of very fine fabrics 7 and 8 (fig. 9), the latter is buff and the most frequent; conversely fabric 7 is characterized by a reddish/dark pink colour frequently associated with lighter surfaces, obtained with the same process described for coarse wares. It is not possible to rule out that even these two fine fabrics are composed of the same or very similar clays, obtained from only one or closed supply areas.

Most jugs have moulded relief decoration, created with the use of hemispherical moulds. On account of the variety and the richness of the decorative repertoire (geometric, vegetal, zoomorphic and pseudo-epigraphic motifs), these jugs have been the most studied and published among the ceramic finds from Estakhr. ${ }^{14}$

\subsection{Glazed pottery}

While unglazed ceramic finds constitute around 93.7\% (5813 specimens) of the bulk of the corpus, the glazed class only amounts to 396 fragments, corresponding to $6.3 \%$.

Most glazed vessels are fine wares made of quite fine fabrics ranging from buff to a reddish colour, two of the five so far identified show a good assortment of small mineral inclusions.

Some fragments belonging to large jars and a few basins are characterized by the same coarse fabrics as the unglazed pottery (sample 7, fig. 10; see Felici, below). Thus, at least for these latter vessels, we could almost certainly suggest local production.

The glazed class comprises a good variety of wares, which largely conform to the Iranian ceramic horizon between the $9^{\text {th }}$ and $12^{\text {th }}$ centuries. Monochrome wares are the most common with green monochrome prevailing. Yellow monochrome specimens are less frequent, and there are also some fragments covered by colourless glaze and only one with brown glaze, belonging to a jug or a bottle. Within the monochrome green ware many forms have been recognized: most are bowls, with everted or thickened rim and rounded body, usually combined with ring bases; there are also a few small basins and some lamps with an open reservoir; while there are fewer closed forms represented by small jars with a short neck and handled jugs (Inv. no. ES 160, fig. 11).

While these monochrome wares are only associated with transparent glazes, with or without white slip, the monochrome turquoise glazed ware also includes a good number of vessels covered with opaque glaze containing tin, as confirmed by preliminary archaeometric tests (Inv. no. ES 121, sample 8, fig. 12; see Felici, below). Monochrome

14 See, for example, Asadi 2005 and Nováček 2009. One specimen is also quoted in Baer 1989, 86-88, fig. 8. 
turquoise ware consists of bowls as well as a good number of small basins, which are sometimes carinated and bear finger-impressed and incised decoration.

The glazed class also comprises graffita monochrome green and monochrome yellow wares, along with splashed graffita ware. This latter consists of conical bowls with ring bases, characterized by the use of thick white slip and the combination of green with brown and/or mustard yellow splashes. A smaller number of splashed ware specimens are also included. Only two fragments with underglaze painted decoration were found in the whole corpus: one from SU 160 has brown and yellow painting; the other one - Inv. no. ES2 from SU114 - may also belong to splashed graffita ware as it is very badly preserved. This evidence may confirm that this kind of ware was not as widespread in Southern Iran as it was in Northern Iran and Central Asia in the same period; therefore these vessels from Estakhr may be imported.

A very small number of badly preserved fragments of green/turquoise monochrome jars of the late Sasanian-early Islamic type have also been identified; we cannot exclude that some items could have been imported.

A few earthenware fragments are absolutely worth mentioning, mostly belonging to large bowls and big dishes, covered by thick opaque white glaze (8 fragments), and some sherds also featuring an inglaze brown and green/turquoise splashed decoration (8 fragments; Inv. no. ES 112, fig. 13). This distinct ware can be considered quite high-quality production, usually attributed to the $9^{\text {th }}-10^{\text {th }}$ century. ${ }^{15}$ It has been identified in different regions of the Islamic world, from Egypt to Central Asia, but its provenance is still debated. A study on fragments from Estakhr is currently underway, also with the support of archaeometry, and it could contribute to further the research on this peculiar ware.

The glazed pottery also comprises four stonepaste fragments, for which three fabrics have been distinguished on the basis of variation in the hardness and compactness. They are monochrome: two covered by opaque white and opaque turquoise glaze respectively and two fragments characterized by transparent turquoise glaze (Inv. no. ES13 from SU 120 and Inv. no. ES93/sample 11 from SU 140). These findings constitute important chronological evidence as they help to date the related archaeological contexts more precisely, giving the terminus post quem of the mid- $11^{\text {th }}$ century (see Mancini, below). ${ }^{16}$

Some imports have been also recognized. Most of the vessels imported at Estakhr belong to the so-called 'Samarra Horizon' $\left(9^{\text {th }}-10^{\text {th }}\right.$ century), as yet underlined by Schmidt in his short report ${ }^{17}$. They include four small bowls or dishes with opaque glaze and seven early lustre ware specimens, both monochrome and polychrome, the latter being very high quality products. One stoneware specimen covered by transparent olive-greenish glaze, collected in SU 141, could possibly be interpreted as a Far-Eastern import. Indeed items brought from the Far East surely circulated at Estakhr, as testified also by Schmidt, who

15 See, for example, Schmidt 1939, 112, fig. 78, Mason and Keall 1991; Mason and Tite 1997; Mason 1997a; Mason 1997b; Watson 2004.

16 A recent study proved that specific monochrome stonepaste specimens were in use in Iran at least since the last quarter of the $11^{\text {th }}$ century: Rugiadi 2010, 181; Rugiadi 2011, 242.

17 Schmidt 1939, 113-115. 
reported that "also fragments of imported Chinese T'ang ware” were found. ${ }^{18}$ In addition to stonepaste fragments, all these imports constitute valuable evidence which is useful to specify the chronological attribution of ceramic assemblages and of their archaeological contexts (see Mancini, below).

Agnese Fusaro

\section{POTTERY IN THE PHASES}

\subsection{Phase 1}

This phase was recognized outside the mosque wall. There is no ceramic evidence from this phase because it corresponds exclusively to the mosque wall and its related semicircular tower (WSU 1, WSU 2).

\subsection{Phase 2}

This phase relates to a sewer covered by a stretch of paved street. Both glazed and unglazed pottery were found in the filling of the sewer (SU 183, SU 184).

Unglazed pottery is exemplified by a few fragments: five coarse sherds decorated with combed and carved motifs, and fine jugs with moulded relief decoration.

As for the glazed pottery, monochrome ware is attested by four fragments covered with transparent green glaze and two fragments of splashed ware with transparent colourless glaze and yellow-green splashes.

This phase can be dated from the $9^{\text {th }}$ to the $10^{\text {th }}$ century.

\subsection{Phase $2 a$}

This phase relates to two elements, both located west of the street and at the same level as Phase 2. The first is a compact floor level found immediately to the west of the street (SU 176). A tannur is embedded into the floor (SU 188) and appears to have been cut by a later construction, probably no earlier than the $11^{\text {th }}$ century (see Phase 3 ). The second element is represented by the northeast corner of a room located at the western end of the trench (WSU 155 and 196).

As for the unglazed pottery (93\%), ${ }^{19}$ fabric groups 1 and 4 (fig. 4) are well attested with many sherds showing combed or carved decoration. Some fragments have a black or red coating, the black slip being more frequent than the red slip. Monochrome painted decoration is also attested, the black painting is usually more frequent whereas red painted decoration has been identified only on four fragments (SU 158). Both decorations and coatings have been found to be associated with both coarse and fine wares. There are also some fragments of fine jugs with moulded relief decoration and vertical ribbon or tubular handles (fabrics 7 and 8; fig. 9) and four fragments of cooking vessels produced with fabric 5 , one of which also has a polished surface.

18 Schmidt 1939, 118

19 All percentage numbers refer to the pottery found in the phase. 
The glazed pottery (7\%) is characterized by monochrome glazed sherds with transparent green and turquoise glazes, some of which are made of coarse fabrics belonging to fabric group 1, while there are only two fragments with transparent yellow glaze (SU 158); a monochrome turquoise spout probably belongs to a lamp. There are also a few sherds of splashed ware with white slip, transparent colourless glaze, and yellow and green splashes; splashed graffita ware was also found (Inv. no. ES 155, sample 43, fig. 14; see Felici, below).

Diagnostic glazed imported specimens, belonging to the so-called 'Samarra Horizon', were recognized: two early monochrome lustreware fragments (SU 168; Inv. no. ES 157, fig. 15) and two opaque white glazed ware fragments, one of them featuring turquoise splashes (SU 158).

Moreover, there is only one fragment with brown and dark yellow underglaze painted decoration.

These evidences suggest that Phase $2 \mathrm{~A}$ could date to the $10^{\text {th }}$ century, and most probably to the second half of it.

\subsection{Phase 3}

This phase is the result of a complete makeover of the area overlooking the west side of the street. The walls were built ex novo from the foundations and cut the tannur found in Phase 2a.

Generally, pottery relating to this phase is sparse and not diagnostic. As for the glazed ware, the very poor preservation of the sole shard found does not allow us to recognize the associated ware (SU 180). The unglazed class is represented by: two of the most typical small basins found at Estakhr (SU 115); ten fragments of coarse ware with combed and carved decoration, but no slipped or painted specimens were found; a few coarse fragments, one of which seems to belong to a cooking pot and shows traces of fire (SU 180); and five fragments of fine jugs with moulded relief decoration.

Due to the absence of diagnostic sherds, we can suggest a probable dating for this phase to the $11^{\text {th }}$ century, according to the ceramic material present in the upper and lower layers.

\subsection{Phase 4}

This phase is associated with the abandonment of the street. The closing down of a tannur (SU 179) located at the door of the mosque (SU 185) is evidence of the presumed decline of this area.

As regards the unglazed pottery, a few sherds with black and red painted decoration characterized by a coarse fabric were found, and two fragments with red slip were also uncovered. There are some sherds of jars made with coarse fabrics belonging to groups 1 and 4, a few of which have fire traces along the rims. One jar fragment has applied decoration.

There are also some fragments of moulded fine jugs, fabric 8 being the most used.

There are only five fragments of glazed pottery: monochrome specimens with turquoise glaze, both transparent and opaque (fig. 12), or green glaze, among them one sherd is made of a coarse fabric; only one fragment of splashed ware was found.

These fragments allow us to date the phase to no later than the $11^{\text {th }}$ century. 


\subsection{Phase 5}

This phase is associated with the collapse of the western wall of the mosque (SU 119, 141, 146 and 135) and the abandonment of the area, while in the meantime the street was covered by layers corresponding to a narrower path to the west (SU 163, 152 and 159).

Among the unglazed pottery (92\%) made of coarse fabrics (fabric groups 1 and 4) combed and carved decorations are the most common, but we have also identified many sherds with red or black painted decoration and, as previously noted in Phase 2a, black painting is more frequent than red (fig. 6). The use of both red or black slips is well attested and in most cases the slip is uniformly applied. Moreover, we found some fragments that may belong to cooking pots (fig. 7) as suggested by fabric 5 and the associated forms.

As for the forms, in SU 129 in particular there are many small basins made of a quite fine fabric but with many voids and/or vegetal temper (Inv. no. ES 140, fig. 16); there are also some large lids or trays, which are not so common in this pottery corpus and whose function is still unclear. Some specimens of large jars have been also recognized.

As for the moulded ware, many fragments were found (17\% of the unglazed pottery) in this phase (fig. 17); some fine jugs are well preserved making it easier to recognize the relief decoration: geometric and vegetal motifs are more frequent than zoomorphic ones, the latter usually represented by small birds or fishes. Furthermore, we also found two small animal figurines (SU 129, SU 133), manufactured with medium coarse buff clay.

A kiln peg (from SU 120) and four fragments of moulds (fig. 2) for producing fine jugs were found, thus confirming the role of Estakhr as a pottery production centre at least during this period.

Three fragments of sphero-conical vessels were also found, one of which has incised decoration.

All glazed wares (8\%) identified within the corpus are attested in this phase. We found numerous fragments of monochrome ware with green, yellow, colourless, turquoise (opaque and transparent) glaze and only one fragment of monochrome brown ware, the latter colour glaze is only present in this phase. There are splashed ware specimens, with both transparent and opaque glaze, and splashed graffita ware; a few sherds of graffita monochrome ware with colourless, green or yellow glaze were also recovered. Monochrome green and monochrome turquoise wares were manufactured with both fine and coarse fabrics (fig. 10).

Moreover, together with the sherd found in Phase 2a, another specimen of underglaze painted ware was found in SU 114 (Inv. no. ES2): this small conical bowl has a simple flat rimmed edge on the exterior and a concave disc base on the interior.

The diagnostic specimens within this phase are: a few fragments of jars of the late Sasanian-early Islamic type, five fragments of imported Early Lustreware (four monochrome lustrewares and one polychrome), two fragments of the so-called 'Samarra Horizon' (one with opaque white and the other with opaque blue glaze); and four glazed monochrome stonepaste fragments (from the mid- $11^{\text {th }}$ century).

It is worth mentioning the finding of a small fragment of stoneware covered with a transparent dark green glaze, which may have been imported from the Far East (SU 141). 
According to the stratigraphic layers, associated with a collapse, it is evident that the pottery found is highly mixed and the assemblage includes all the wares dating from at least the $9^{\text {th }}$ to the $12^{\text {th }}$ century. Accordingly, the phase is dated to the 11 th- 12 th century.

\subsection{Phase 6}

Phase 6 is represented by a wall oriented east-west, located on the western side of the trench (WSU 147). The structure rests on an earthy layer and covers the walls below (Phase 3). wall.

This phase does not contain ceramic material because it corresponds exclusively to the

\subsection{Phase 7}

This phase mainly consists of a pottery dump (SU 142) located more or less in the middle of the trench.

The unglazed vessels were mostly produced with fabric belonging to fabric groups 1 and 4, among which there are some small basins, a pot, a small lid with a preserved handle, jars and jugs of different dimensions.

Many fine jugs with moulded relief decoration are attested, and one fragment displays a pseudo-Kufic motif (Inv. no. ES27 from SU 118).

A horse-shaped figurine made with fabric 4 (SU 102) was also found.

Finally, there is also one fragment from a sphero-conical vessel.

As far as the glazed ware is concerned, there are many fragments of monochrome ware, covered with transparent green, yellow, opaque and transparent turquoise glaze; vessels with green glaze are more frequent, there are also a few fragments belonging to monochrome graffita ware (fig. 18). Some specimens of monochrome green or turquoise wares are made of coarse fabrics (fabric groups 1 and 4). There are also glazed vessels with splashed decoration and other sherds belonging to the distinct ware covered with opaque white glaze (see Fusaro, above).

Some specimens have been identified as imports: two early monochrome lustreware fragments related to the 'Samarra Horizon' and one jar of the Sasanian-early Islamic type, probably from another Iranian centre.

In SU 142 the archaeologists found a kiln peg characterized by glaze drops (fig. 3), important evidence of local pottery production.

Pottery assemblages associated with Phase 7 are quite similar to those related to Phase 5 , and for this reason we can suggest a similar dating $\left(9^{\text {th }}-12^{\text {th }}\right.$ century).

Serenella Mancini

\section{CONCLUSIONS}

The preliminary study carried out to date on the ceramics from Estakhr roughly confirms the chronological attribution proposed in the previous 2013 report. ${ }^{20}$ In particular, the time span of the $9^{\text {th }}-12^{\text {th }}$ centuries most likely corresponds to the occupation phases

20 Chegini et al. 2013. 
identified through the analysis of the stratigraphy. This time range is also confirmed by the high homogeneity and uniformity of the Estakhr pottery corpus: despite a few differences, the most common unglazed and glazed wares were found in almost all the layers, without having been affected by any dramatic change over the centuries.

Nonetheless, a comparative study with coeval corpora from other archaeological sites is certainly necessary for a clearer and more precise definition of the chronological attributions proposed for each phase. ${ }^{21}$

Moreover, evidence of local ceramic production and the finding of valuable imports clearly testify Estakhr's role as both a manufacturing centre of unglazed and glazed pottery and as a trading post.

Finally the archeometric analyses currently underway could add new data to the technological and production aspects of the identified wares.

Agnese Fusaro - Serenella Mancini

\section{ARCHAEOMETRIC ANALYSES}

This appendix reports the preliminary results of the analyses performed during the 2015 campaign of the Estakhr Project.

The findings were analysed by means of X-rays fluorescence spectroscopy (XRF), used to carry out a preliminary screening and selection of the most interesting samples directly in the field. ${ }^{22}$

The portable XRF spectrometer used in this work is an energy dispersive one (ED-XRF spectrometer) that can measure the number of X-rays emitted by the sample as a function of their energy (XRF spectrum). It consists of a low power X-ray generator, an X-ray detector, a pulse amplifier, a multichannel analyser and a computer. This instrument can detect all chemical elements from aluminium to uranium with a detection limit of around $10^{3} \mathrm{ppm} .{ }^{23}$ This detection limit means major and minor elements can be revealed, but not trace elements.

The samples were analysed in different areas of approx. $1 \mathrm{~mm}^{2}$, and the analysed volume had a thickness of approx. $10 \mu \mathrm{m}$. For all the XRF spectra the acquisition time was $300 \mathrm{~s}$.

After their acquisition a best fit of the XRF spectra was performed in order to identify the chemical elements present in the material and to obtain, for each of them, the number of photon counts corresponding to its characteristic line. The counts which were less than 3 times the value of the statistic error were discarded. The software for the best fit used in this work was PyMca. ${ }^{24}$

21 Cf., at present, Asadi 2005 and Nováček 2009.

22 The XRF is a technique usefully employed to perform elemental analyses on any kind of material without any destructive sampling. Moreover, the use of portable instrumentation means the analyses can be performed in situ where the object is conserved.

23 Terenzi et al. 2010.

24 Solé et al. 2007 
The number of counts of each characteristic line is proportional to the concentration of the corresponding chemical element and the proportionality coefficient depends on its atomic number.

The analyses focused on ceramic samples, ${ }^{25}$ on which more than 200 measurements were taken.

This appendix only reports the results of the analyses carried out on pottery samples selected for this report and listed in table 1.

The analyses focused on either fabrics and glazes. In particular, for the fabrics, these analyses were useful in selecting the fabric samples to bring to Italy where they are the subject of a more in-depth study using geochemical and mineralogical approaches (XRD, polarizing light microscope and SEM used to examine thin ceramic sections, WD-XRF). The samples were selected according to the following archaeological aims:

For the fabrics:

1) identifying the local unglazed productions by comparing the most common fabrics used for unglazed vessels (fabric groups 1 and 4) (fig. 4) and fabrics used for producing specific objects related to the potter's kiln furniture and the shaping processes, such as kiln pegs (cf. sample 13) and moulds (figs. 2-3), which were almost certainly locally produced.

2) understanding what elements and/or what type of manufacturing process produced the different fabrics seen in fabric group 1 and fabric group 4, the macroscopic aspects of which present many similarities (see Fusaro, above).

3) analysing red and black slips and paintings on unglazed vessels in order to identify their composition. This analysis is useful in solving point 2, because red slip and red painting are almost always both associated with the fabrics of group 4, while black slip and black painting are almost always both associated with the fabrics of group 1 (see Fusaro, above).

For the glazes:

4) identifying the different types of glazes and their composition (alkaline, lead, tin).

5) identifying the local productions of glazed pottery produced with fine fabrics: generally speaking the comparison between these fine glazed ceramics and the other wares of the pottery corpus - in order to understand whether they are locally produced or not - is more difficult and it is necessary to crosscheck several different data related not only to fabrics but also to glazes.

Therefore, besides the petrographic and mineralogical analyses that are being carried out in Italy on the fabrics, it is useful to compare the glazes found on different items:

- objects which were certainly locally produced, in this case a kiln peg with drops of different glazes - sample 13;

- glazed coarse jars which have the same fabrics as the most common unglazed coarse fabrics, which are also the same fabrics as those of the kiln pegs and the moulds (see point 1);

- fine glazed vessels belonging to the most common glazed wares identified for the Estakhr corpus.

25 Besides 47 pottery samples, a few other materials were also analysed in the field: iron slags, fragments of plaster, one bronze coin. 


\subsection{Fabrics}

The comparison of the results obtained from the samples selected for the analyses of ceramic bodies does not reveal any substantial difference in the chemical composition of fabric groups 1 and 4 (figs. 19-20). These very preliminary results may support the hypothesis that the difference between the two fabric groups could be ascribed to the firing temperature and atmosphere rather than to the different materials employed. Nevertheless, since the XRF analysis only provides information on the chemical elements present in the material and not on its mineralogical composition further analyses must be performed to confirm the hypothesis.

The composition of the ceramic finds belonging to fabric groups 1 and 4 does not differ from that of the kiln pegs and moulds (figs. 19-20), and this result is compatible with their attribution of local production. However, in order to confirm the provenance of the finds, other analyses must be performed, aimed at collecting data on trace elements and the mineralogical composition.

The analyses of red and black slips and black painting show that in all cases a clay different from that of the ceramic body (fig. 21:A) and richer in iron (fig. 21:B) has been used. All the samples show a similar composition regardless of the colours of their coatings (fig. 21).

\subsection{Glazes}

The histograms of the XRF counts relative to lead, tin and potassium measured on the glazed surfaces are shown in fig. 22:A.

The results show that all the analysed glazes contain lead, except for two samples with transparent turquoise glaze (sample 7 , fig. 10, and sample 11). The glazes of these two samples should be alkaline, as also suggested by the high level of potassium.

All the opaque glazes contain tin. However, in sample 19 (white glaze) the amount of tin is so low that it is difficult to ascribe the opacity of the glaze to the presence of the latter. Instead, in the transparent glazes the amount of tin is very low or under the detection limit, with the exception of samples 29 and 31 (colourless glaze). For the latter the amount of tin is comparable with that detected in the samples covered with opaque glazes.

The glaze of sample 37 (opaque white glaze), which was almost certainly imported from the Iraqi area, has a different composition to the other opaque glazes, having the highest tin-lead and potassium-lead ratios.

With regard to the minor elements detected in the glazes, the main differences among the samples concern the presence of arsenic, phosphorus and vanadium (fig. 22:B). In particular, all the glaze drops found on the kiln peg (sample 13) contain phosphorus, probably related to the use of ashes as a source of alkaline elements; the only exception is a drop of brown glaze, which does not contain any of those elements.

Phosphorus was also found in all the transparent glazes, except for the three samples with turquoise glaze (samples 7, 11,36), and samples 5 (green glaze) and 6 (colourless glaze).

Vanadium, an element often associated with lead, was detected in the two green and one brown glaze drops found on the kiln peg (sample 13), in all the opaque glazes, except for 
samples 8 (turquoise glaze, fig. 12) and 37 (white glaze), and in transparent green (samples 5, 22 and 49) and colourless (samples 6, 31 and 43, fig. 14) glazes.

Arsenic was detected in the same glaze drops found on the kiln peg (sample 13) containing vanadium, in three opaque glazes (yellowish glaze of sample 15, white glaze of samples 19 and 39), and in the transparent glaze of samples 6, 43 (colourless glaze) and 49 (green glaze).

The green and turquoise colours are due to the presence of copper mixed with small amounts of zinc. In samples 6, 7, 36 and 49 the amount of zinc is higher and the zinccopper ratio is about 1:5.

The brown glaze colour is characterized by an increase in the manganese content, whereas for the time being it is not possible to clearly identify the elements responsible for the yellow glaze colour.

Anna Candida Felici

\begin{tabular}{|c|c|c|c|c|c|}
\hline \multicolumn{6}{|c|}{ Table 1} \\
\hline Samples & $\begin{array}{l}\text { Inv. } \\
\text { nos. }\end{array}$ & $\begin{array}{l}\text { Archaeological } \\
\text { contexts }\end{array}$ & Brief description & Analysis & Notes \\
\hline 5 & & Phase 5 & $\begin{array}{l}\text { wall; } \\
\text { glazed monochrome earthenware; } \\
\text { transparent green glaze }\end{array}$ & glaze analysis & \\
\hline 6 & $\begin{array}{c}\text { ES } \\
130\end{array}$ & Phase 4 & $\begin{array}{l}\text { bowl rim; } \\
\text { glazed splashed earthenware; } \\
\text { transparent colourless glaze, } \\
\text { dark yellow and green splashes }\end{array}$ & glaze analysis & \\
\hline 7 & & Phase 5 & $\begin{array}{l}\text { thick wall, possibly a jar; } \\
\text { probably local fabric; } \\
\text { glazed monochrome earthenware; } \\
\text { transparent turquoise glaze }\end{array}$ & $\begin{array}{l}\text { glaze analysis; } \\
\text { fabric analysis }\end{array}$ & \\
\hline 8 & $\begin{array}{l}\text { ES } \\
121\end{array}$ & Phase 4 & $\begin{array}{l}\text { bowl rim; } \\
\text { glazed monochrome earthenware; } \\
\text { opaque turquoise glaze }\end{array}$ & glaze analysis & \\
\hline 11 & $\begin{array}{c}\text { ES } \\
93\end{array}$ & Phase 5 & $\begin{array}{l}\text { bowl rim; } \\
\text { glazed monochrome stonepaste ware; } \\
\text { transparent turquoise glaze }\end{array}$ & glaze analysis & \\
\hline 13 & & Phase 7 & $\begin{array}{l}\text { kiln peg; } \\
\text { unglazed; } \\
\text { clayey fabric }\end{array}$ & $\begin{array}{l}\text { fabric analysis; } \\
\text { glaze analysis } \\
\text { of drops }\end{array}$ & $\begin{array}{l}\text { reference sample } \\
\text { to determine local } \\
\text { production }\end{array}$ \\
\hline 15 & & survey & $\begin{array}{l}\text { rim of lobed bowl; } \\
\text { glazed monochrome earthenware; } \\
\text { opaque yellowish ware }\end{array}$ & glaze analysis & \\
\hline 19 & & survey & $\begin{array}{l}\text { disc base of bowl; } \\
\text { glazed splashed earthenware; } \\
\text { opaque white glaze, } \\
\text { green/turquoise splashes }\end{array}$ & glaze analysis & \\
\hline 22 & & Phase 2A & $\begin{array}{l}\text { wall, possibly closed vessel; } \\
\text { probably local fabric; } \\
\text { glazed monochrome earthenware; } \\
\text { transparent green glaze }\end{array}$ & $\begin{array}{l}\text { glaze analysis; } \\
\text { fabric analysis }\end{array}$ & \\
\hline 29 & & Phase 5 & $\begin{array}{l}\text { ring base, possibly open vessel; } \\
\text { glazed monochrome earthenware; } \\
\text { transparent colourless glaze }\end{array}$ & glaze analysis & \\
\hline 31 & & Phase 5 & $\begin{array}{l}\text { wall; } \\
\text { glazed monochrome earthenware; } \\
\text { transparent colourless glaze }\end{array}$ & glaze analysis & \\
\hline
\end{tabular}




\begin{tabular}{|c|c|l|l|l|l|}
\hline 36 & $\begin{array}{c}\text { ES } \\
133\end{array}$ & Phase 5 & $\begin{array}{l}\text { disc base; } \\
\text { glazed monochrome earthenware; } \\
\text { transparent turquoise glaze }\end{array}$ & glaze analysis & \\
\hline 37 & $\begin{array}{c}\text { ES } \\
158\end{array}$ & Phase 2A & $\begin{array}{l}\text { bowl rim; } \\
\text { fine buff fabric, probably Iraqi origin; } \\
\text { glazed monochrome earthenware; } \\
\text { opaque white glaze }\end{array}$ & glaze analysis & imported item \\
\hline 39 & & Phase 2A & $\begin{array}{l}\text { wall; } \\
\text { glazed monochrome earthenware; } \\
\text { opaque white glaze }\end{array}$ & glaze analysis & \\
\hline 43 & $\begin{array}{l}\text { ES } \\
\text { ring base of bowl; } \\
\text { splashed graffita earthenware; } \\
\text { transparent colourless glaze, } \\
\text { dark yellow, green and brown } \\
\text { splashes }\end{array}$ & $\begin{array}{l}\text { Phase 2A } \\
\text { thick wall; } \\
\text { probably local fabric; } \\
\text { glazed monochrome earthenware; } \\
\text { transparent green glaze }\end{array}$ & glabis & glaze analysis; \\
fabric analysis & & \\
\hline 49 & Phase 2A & &
\end{tabular}

This project is sponsored by the Max van Berchem Foundation, established in 1973 in memory of Max van Berchem (1863-1921), the founder of Arabic epigraphy. Based in Geneva, the aim of the Foundation is to promote the study of Islamic and Arabic archaeology, history, geography, art, epigraphy, religion and literature.

\section{REFERENCES}

ASADI, A.

2005 Istakhr City During the Historical Periods with a Focus on the Sasanian Era. An Archaeological Investigation. MA Thesis, Tehran University (unpublished).

BAER, E.

1989 Jewelled Ceramics from Medieval Islam. A Note on the Ambiguity of Islamic Ornament: Muqarnas 6 (1989), pp. 83-97.

Chegini, N.N.Z. - Fontana, M.V. - Asadi, A. - Rugiadi, M. - JaiA, A.M. - Blanco, A. - Ebanista, L. - CIPOLLARI, V.

2013 Estakhr Project - Second Preliminary Report of the Joint Mission of the Iranian Center for Archaeological Research, the Parsa-Pasargadae Research Foundation and the Sapienza University of Rome, Italy: Vicino Oriente XVII (2013), pp. 7-20.

CUOMO DI CAPRIO, $\mathrm{N}$.

2007 La ceramica in archeologia 2. Antiche tecniche di lavorazione e moderni metodi di indagine. Nuova edizione ampliata, Rome 2007.

Fontana, M.V. - Mireskandari, S.M. - Rugiadi, M. - Asadi, A. - JaiA, A.M. - Colliva, L. Blanco, A.

2012 Estakhr Project - First Preliminary Report of the Joint Mission of the Iranian Center for Archaeological Research, the Parsa-Pasargadae Research Foundation and the Sapienza University of Rome, Italy: Vicino Oriente XVI (2012), pp. 167-180. 
MAggetti, M. - NeURURER, CH. - RAMSEyer, D.

2011 Temperature Evolution Inside a Pot During Experimental Surface (Bonfire) Firing: MASON, R. B. Applied Clay Science 53 (2011), pp. 500-508.

1997a Early Medieval Iraqi Lustre-Painted and Associated Wares: Typology in a Multidisciplinary Study: Iraq 59 (1997), pp. 15-61.

1997b Medieval Egyptian Lustre-painted and Associated Wares: Typology in a Multidisciplinary Study: Journal of the American Research Center in Egypt 34 (1997), pp. 201-242.

MASON, R. B. - KEALL, E. J.

1991 The 'Abbāsid Glazed Wares of Sīrāf and the Bașra Connection. Petrographic Analysis: Iran 29 (1991), pp. 51-66.

MASON, R. B. - TITE, M. S.

1997 The Beginnings of Tin-Opacification of Pottery Glazes: Archaeometry 39/1 (1997), pp. 41-58.

MIRTI, P.

1998 On the Use of Colour Coordinates to Evaluate Firing Temperatures of Ancient Pottery: Archaeometry 40, 1 (1998), pp. 45-57.

MiRTi, P. - DAVIT, P.

2004 New Developments in the Study of Ancient Pottery by Colour Measurement: Journal of Archaeological Science 31 (2004), pp. 741-751.

NOVÁČEK, K.

2009 Chapter 13, Moulded Pottery from Istakhr: P. MǍ̌íKOVÁ VlČKOVÁ - J. MYNÁŘovÁ - M. TOMÁšEK (eds.), My Things Changed Things. Social Development and Cultural Exchange in Prehistory, Antiquity and Middle Ages, Charles University in Prague, Faculty of Arts, Institute of Archaeology of the Academy of Sciences of the Czech Republic, Prague 2009, pp. 118-126.

RUGIADI, M.

2010 Processing Iranian Glazed Pottery of the Masjid-i Jum'a in Isfahan (ADAMJI Project): Fritwares from the foundations of Nizām al-Mulk’s Domed Hall: P. MATTHIAE - F. PinnoCK - L. Nigro - N. MarChetTi (eds.), Proceedings of the $6^{\text {th }}$ ICAANE Congress, Rome 5 May - 10 May 2008, “Sapienza” Università di Roma, III, Wiesbaden 2010, pp. 173-190.

2011 The Emergence of the Siliceous-paste in Iran in the Last Quarter of the $11^{\text {th }}$ Century and Related Issues. The Dated Assemblage From the Southern Domed Hall of the Great SCHMIDT, E. Mosque of Isfahan: Vicino e Medio Oriente, XV (2011), pp. 233-248.

1939 The Treasury of Persepolis and Other Discoveries in the Homeland of the Achaemenians, Chicago 1939.

$1970 \quad$ Persepolis, III. The Royal Tombs and Other Monuments, Chicago 1970

Sole, V.A. - PAPILlon, E. - CotTe, M. - Walter, Ph. - Susini J.

2007 A Multiplatform Code for the Analysis of Energy-dispersive X-Ray Fluorescence Spectra: Spectrochimica Acta Part B 62 (2007), pp. 63-68.

Terenzi, C. - Casieri, C. - Felici, A.C. - Piacentini, M. - Vendittelli, M. - De LuCA, F.

2010 Characterization of Elemental and Firing-Dependent Properties of Phlegrean Ceramics by Non-Destructive ED-XRF and NMR Techniques: Journal of Archaeological Science 37 (2010), pp. 1403-1412.

WATSON, O.

2004 Opaque White Glazed Wares: O. WATson, Ceramics from Islamic Lands, London 2004, pp.171-181. 


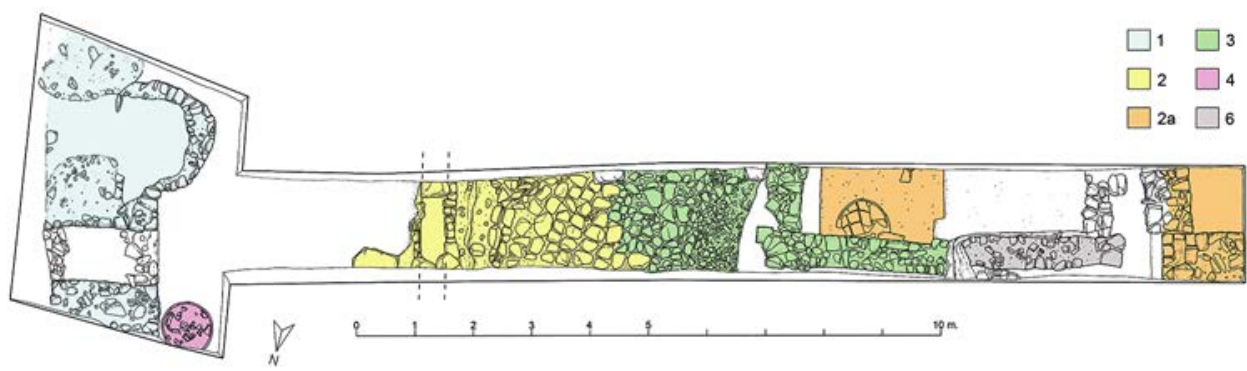

Fig. 1 - General map of the trench: phase 1 - light blue; phase 2 - light ochre; phase 2A ochre; phase 3 - green; phase 4 - pink; phase 6 - grey (rendering A.M. Jaia).

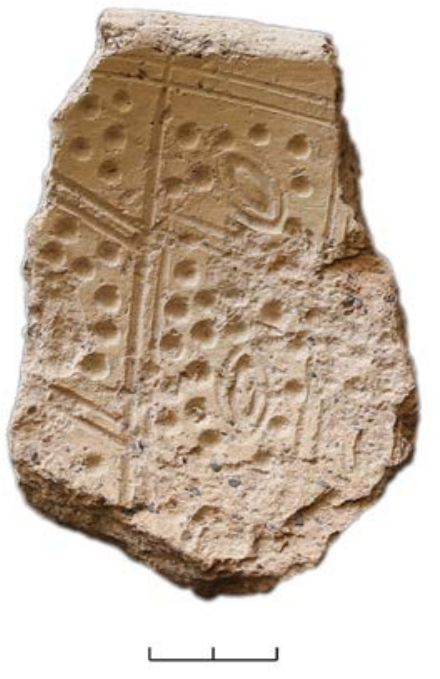

Fig. 2 - Pottery mould with carved decoration, phase 5 (photo S. Mancini).

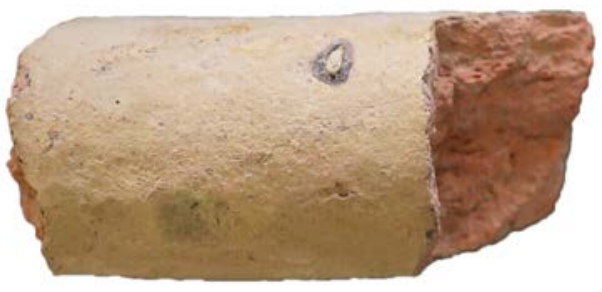

Fig. 3 - Kiln peg with drops of glazes, sample 13, phase 7 (photo S. Mancini). 

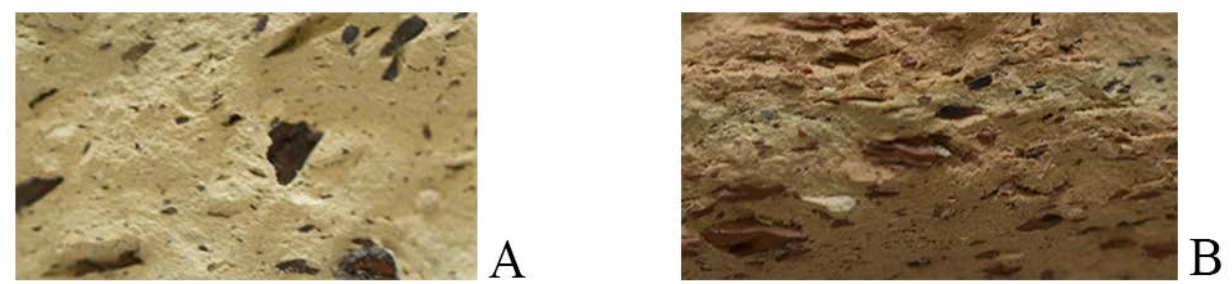

Fig. 4 - A: Coarse fabric-group 1; B: coarse fabric-group 4 (photo S. Mancini).

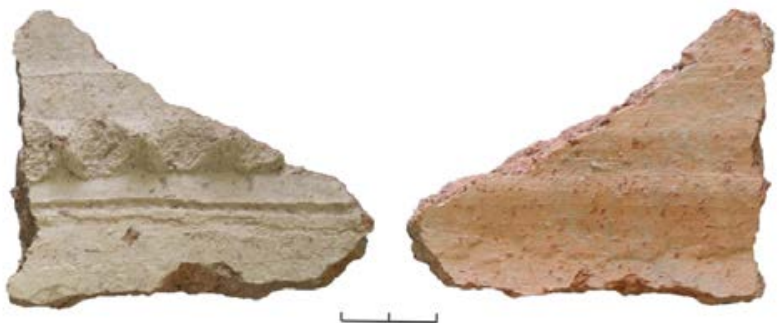

Fig. 5 - Fragment of unglazed coarse jar, characterized by whitish surfaces, with applied strip and finger-impressed decoration: obverse and reverse, phase 7 (photo S. Mancini).

Fig. 6 - Unglazed earthenware closed vessel, probably a jar or a jug, with incised and black painted decoration, phase 5 (photo S. Mancini).
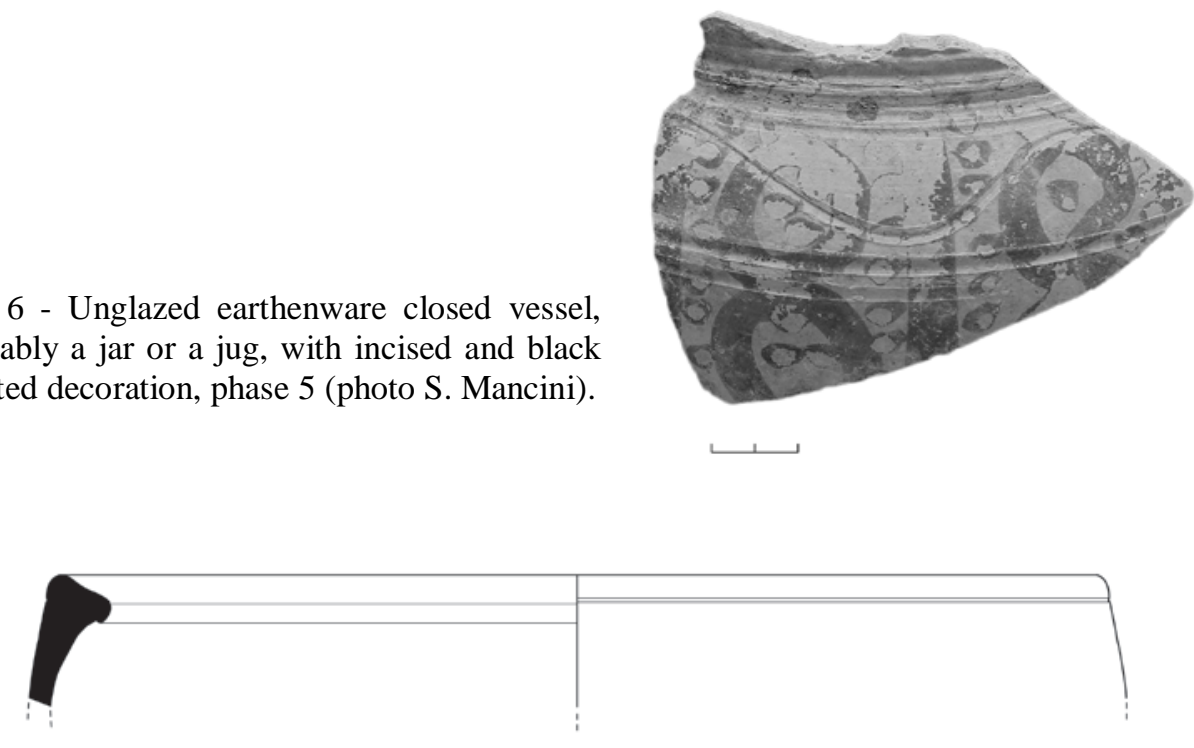

Fig. 7 - Unglazed earthenware cooking pot, Inv. no. ES135, phase 5 (drawing A. Fusaro). 


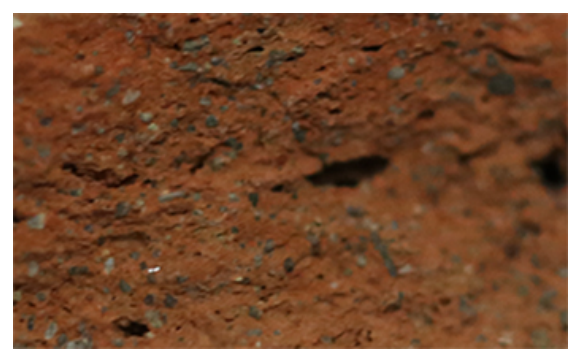

Fig. 8 - Coarse fabric 5 (photo S. Mancini).
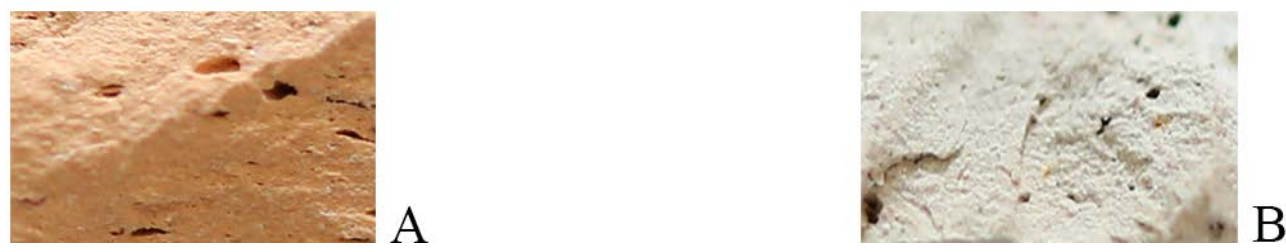

Fig. 9 - A: Fine fabric 7; B: fine fabric 8 (photo S. Mancini).

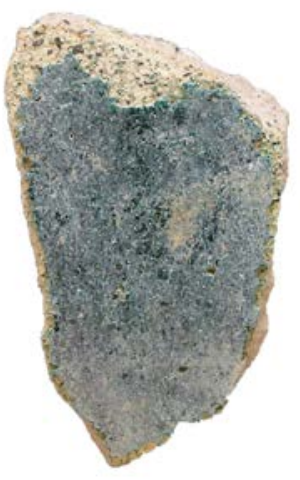

Fig. 10 - Glazed turquoise monochrome earthenware fragment, made of a coarse fabric, probably belonging to a jar, Sample 7, phase 5 (photo S. Mancini).
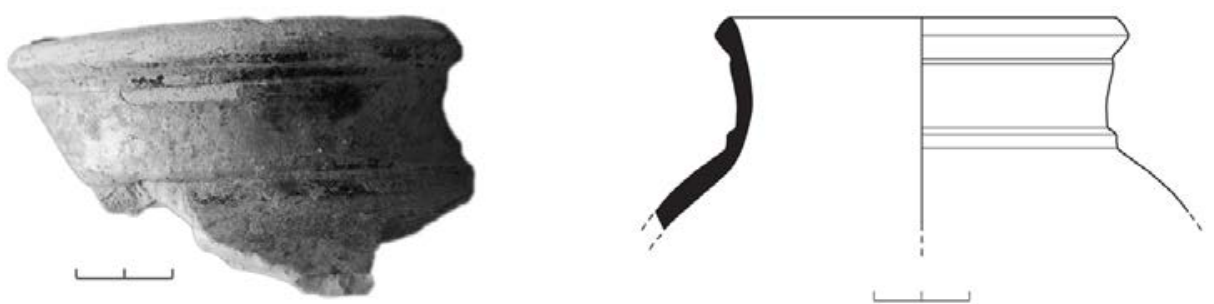

Fig. 11 - Glazed green monochrome earthenware small jar, Inv. no. ES160, phase 5 (photo S. Mancini; drawing A. Fusaro). 

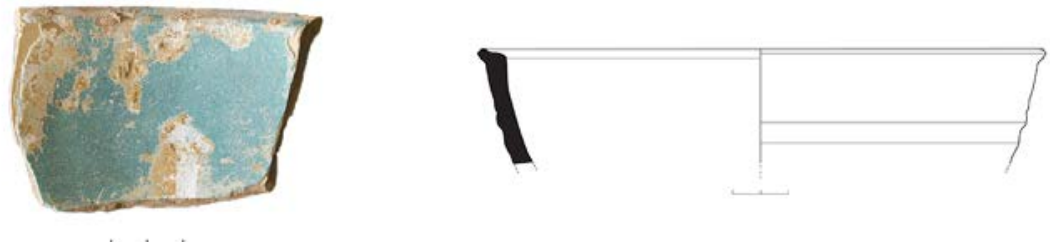

Fig. 12 - Glazed monochrome earthenware bowl with opaque turquoise glaze, sample 8, Inv. no. ES121, phase 4 (photo S. Mancini; drawing A. Fusaro).
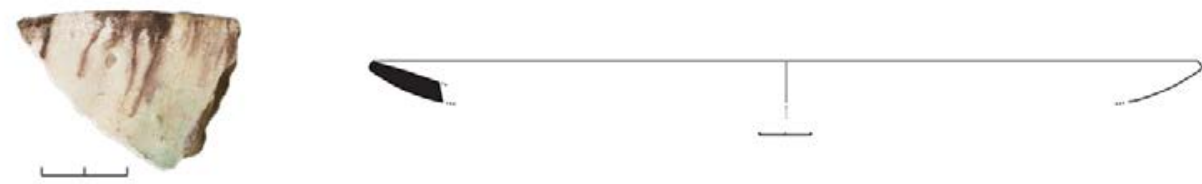

Fig. 13 - Opaque white glazed bowl with splashes, Inv. no. ES112, phase 5 (photo S. Mancini; drawing A. Fusaro).
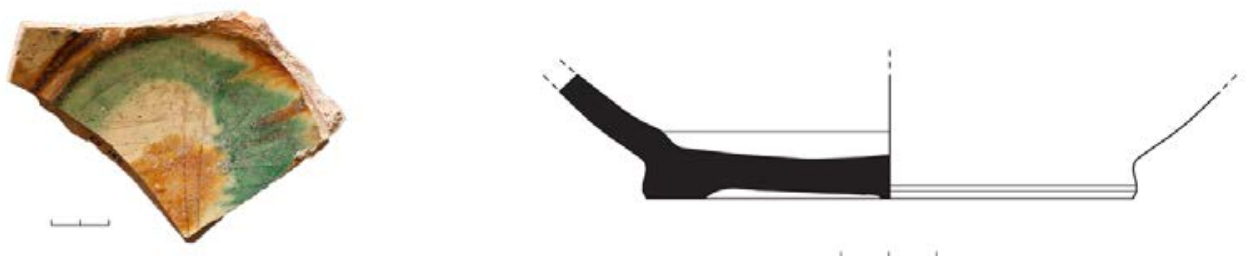

Fig. 14 - Glazed splashed graffita earthenware bowl, Inv. no. ES155, sample 43, phase 2A (photo S. Mancini; drawing A. Fusaro).
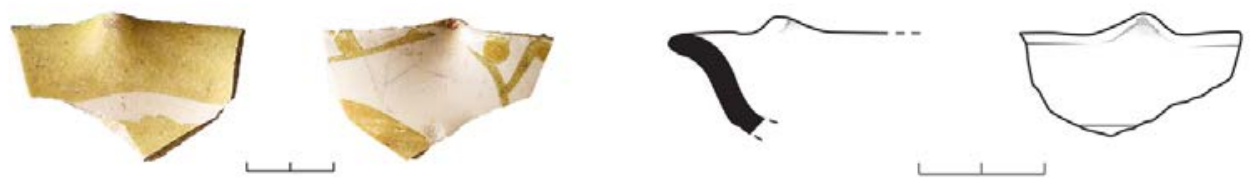

Fig. 15 - Monochrome Abbasid lustreware small bowl: obverse and reverse, Inv. no. ES157, phase 2A (photo S. Mancini; drawing A. Fusaro). 

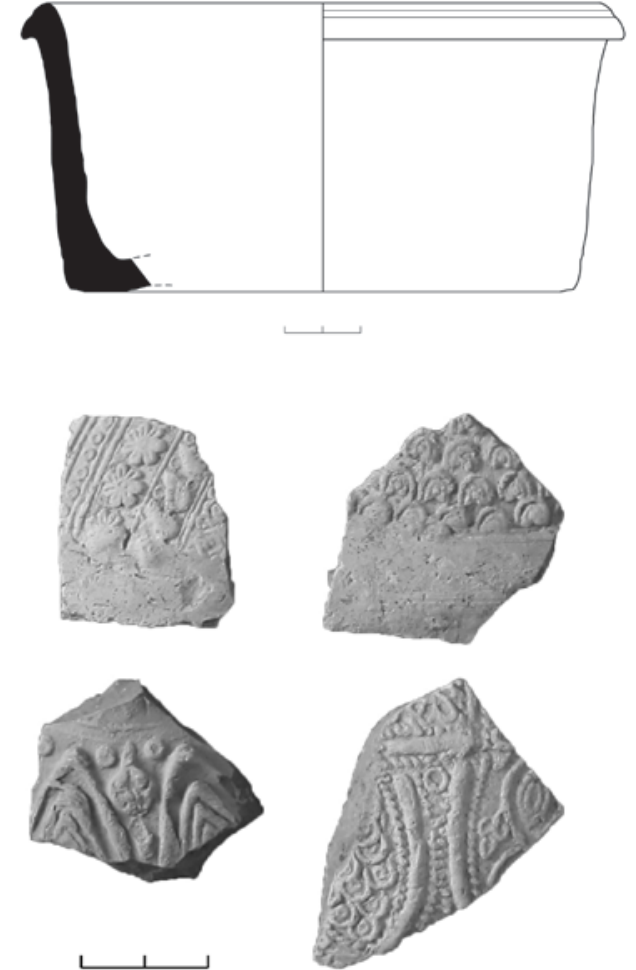
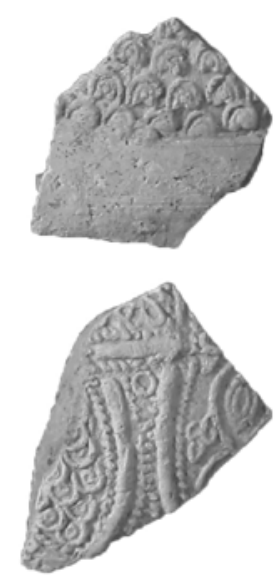

Fig.16 - Unglazed earthenware small basin, Inv. no. ES140, phase 5 (drawing A. Fusaro).

Fig. 17 - Fragments of unglazed earthenware jugs with moulded relief decoration, phase 5 (photo S. Mancini).

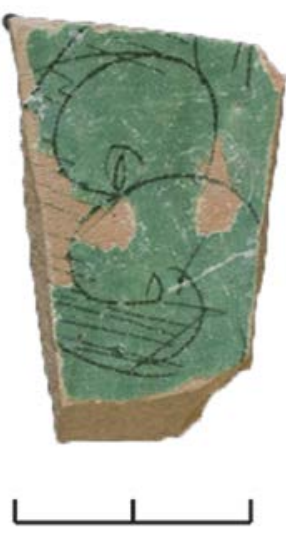




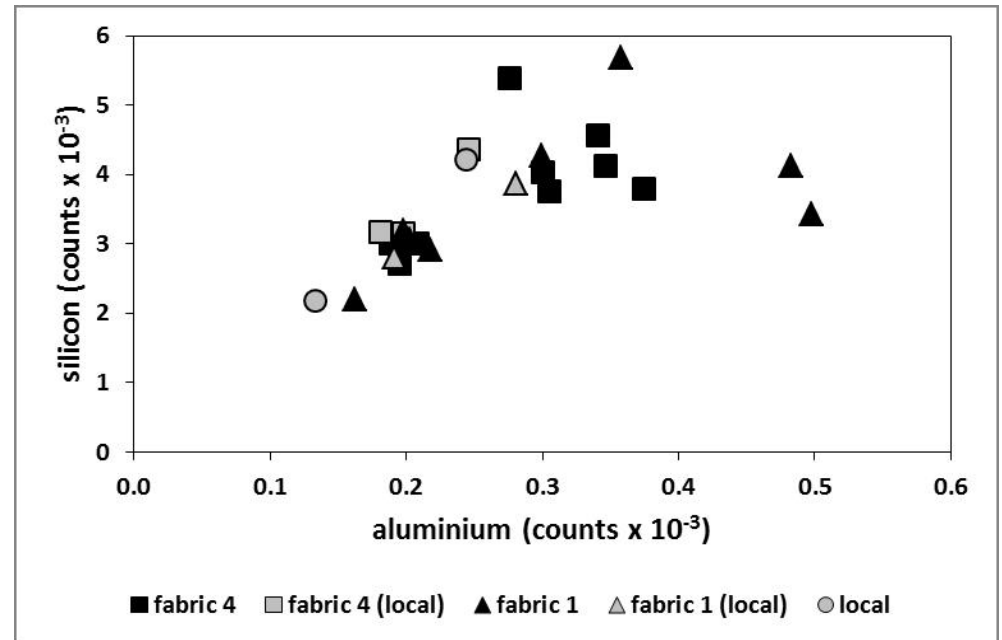

A

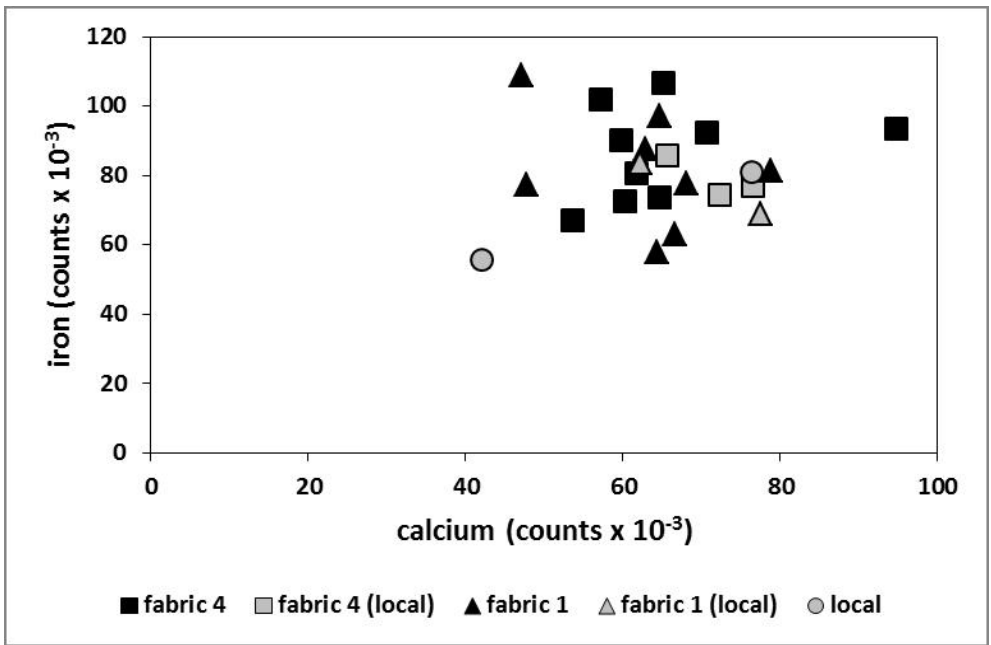

B

Fig. 19 - Binary plots of major elements' XRF counts measured in the ceramic body of fabric-groups 1 and 4. A: silicon versus aluminium, B: iron versus calcium (rendering A.C. Felici). 


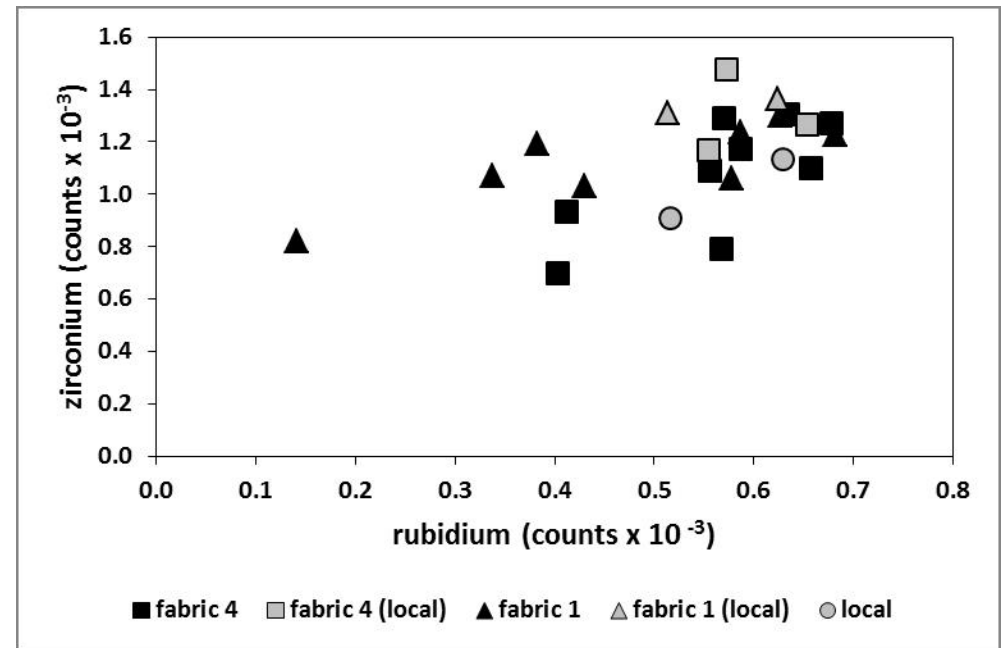

A

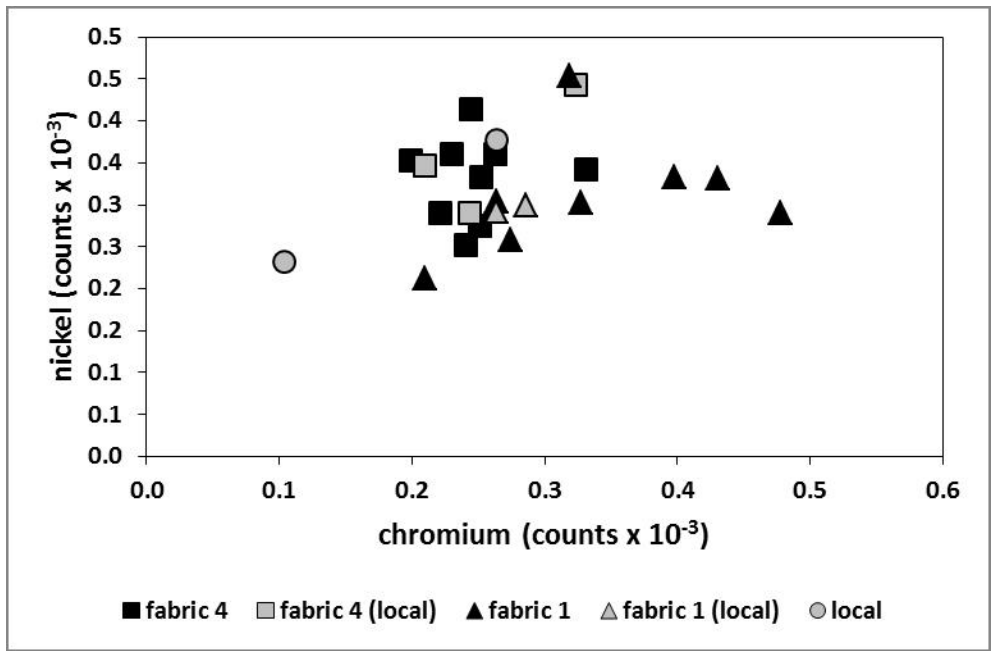

B

Fig. 20 - Binary plots of minor elements' XRF counts measured in the ceramic body of fabric-groups 1 and 4. A: zirconium versus rubidium, B: nickel versus chromium (rendering A.C. Felici). 


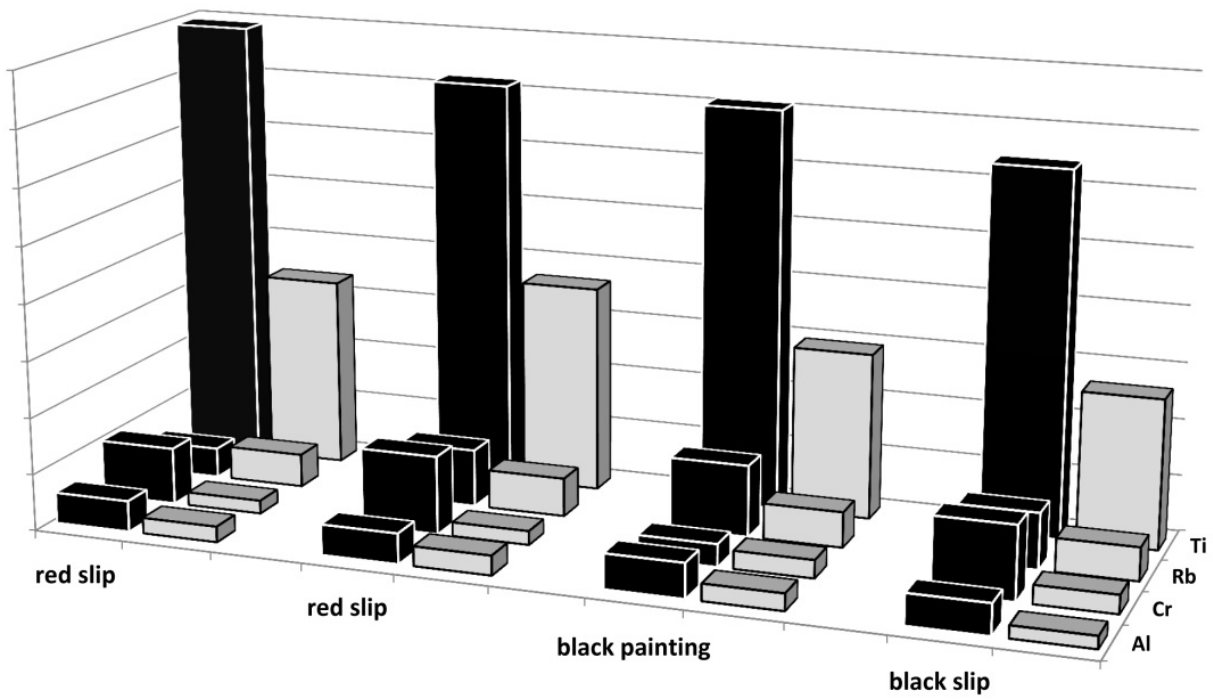

A

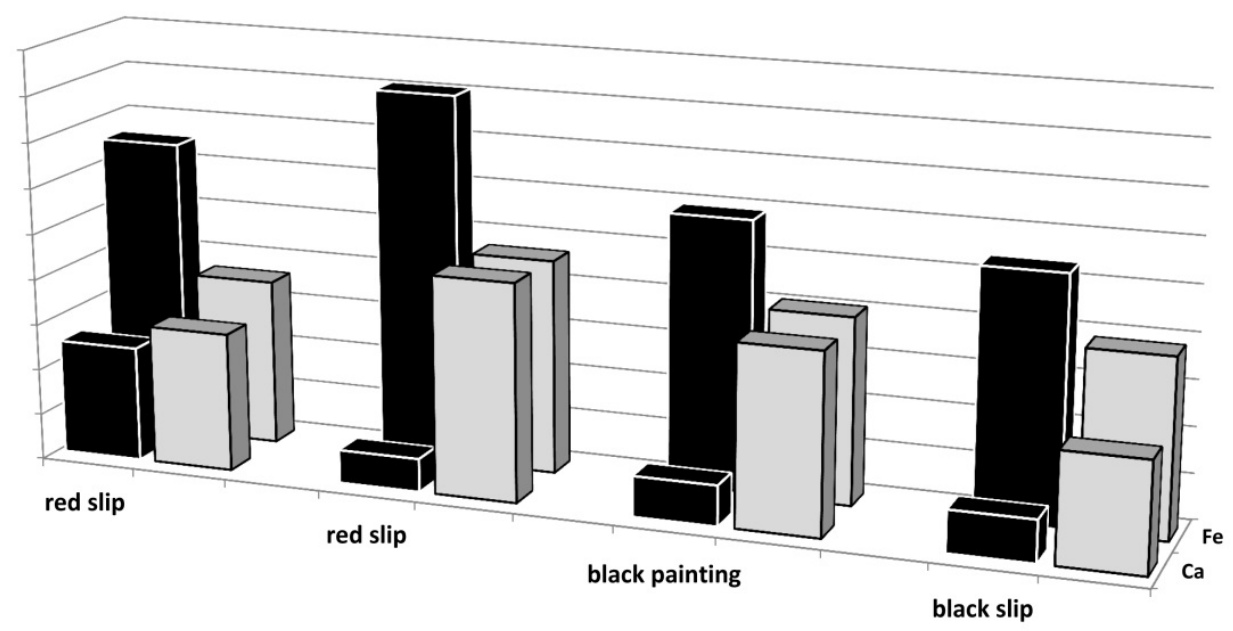

B

Fig. 21 - Histogram of the XRF counts measured on the painted surface (black) and in the ceramic body (grey). A: aluminium (Al), chromium (Cr), rubidium (Rb) and titanium (Ti); B: calcium (Ca) and iron (Fe) (rendering A.C. Felici). 

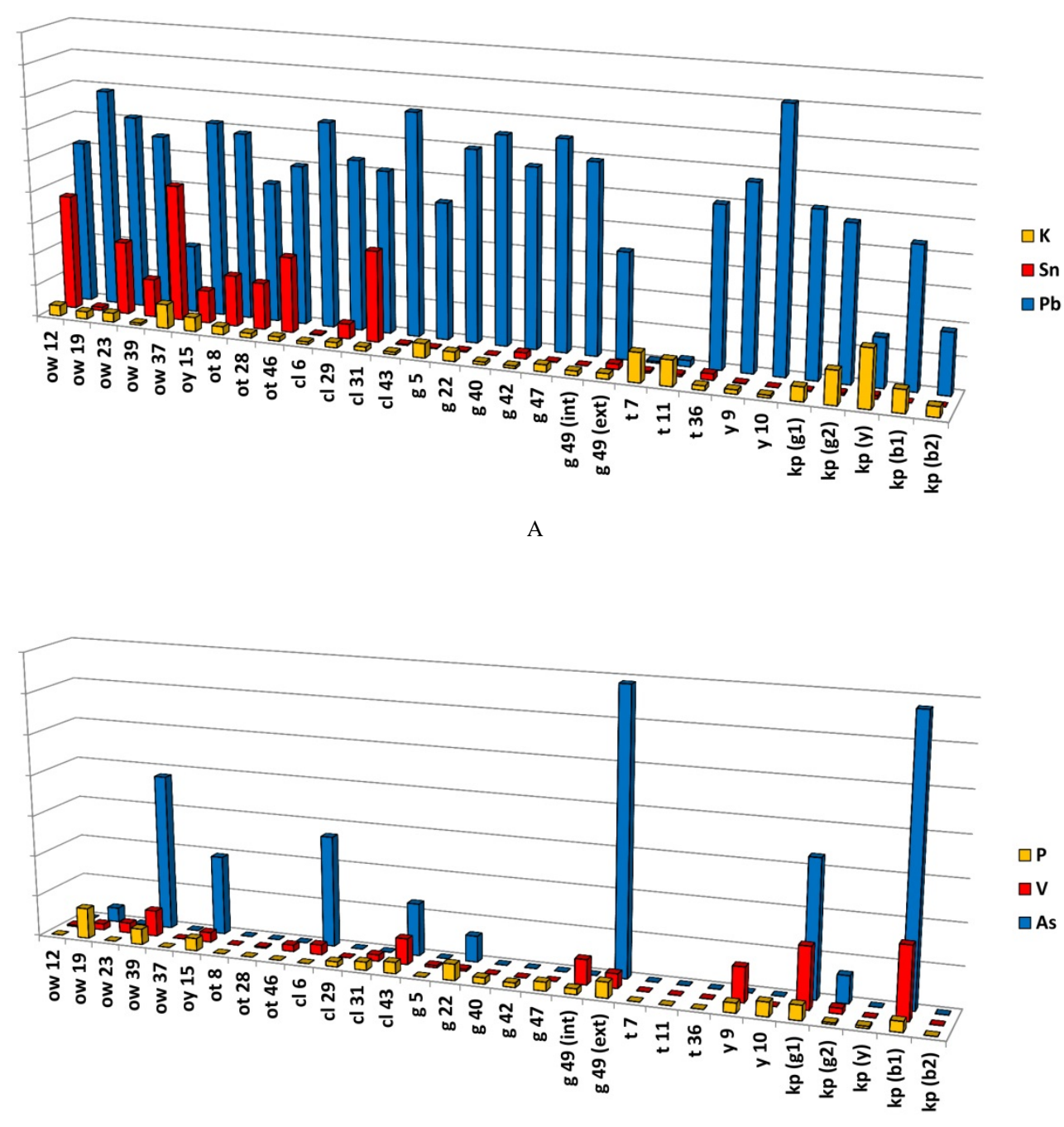

B

Fig. 22 - Histogram of the XRF counts measured in the glaze. A: potassium (K), tin (Sn) and lead $\left(\mathrm{Pb}\right.$; for lead the counts are multiplied by $\left.10^{-1}\right)$; $\mathrm{B}$ : phosphorus $(\mathrm{P})$, vanadium $(\mathrm{V})$ and arsenic (As) (rendering A.C. Felici).

Legend: ow = opaque white; oy = opaque yellow; ot = opaque turquoise; $\mathrm{cl}=$ colourless; $\mathrm{g}$ $=$ transparent green; $\mathrm{t}=$ transparent turquoise; $\mathrm{y}=$ transparent yellow; $\mathrm{kp}=$ kiln peg. 